\title{
IMPLEMENTASI SAAT TEDUH SEBAGAI GAYA HIDUP MAHASISWA TEOLOGI DALAM USAHA PEMBENTUKAN KARAKTER TAHAN UJI TERHADAP PERKEMBANGAN TEKNOLOGI
}

Oleh :

\author{
Yelka Sania Datu \\ Mahasiswa Institut Agama Kristen Negeri Toraja
}

\section{ABSTRAK}

Adanya perkembangan teknologi sangat memudahkan manusia dalam menjalankan aktifitas, mencari dan bahkan mendapat informasi. Namun, haruslah perkembangan teknologi ini disikapi dengan baik, khususnya oleh mahasiswa Teologi. Mereka harus membangun gaya hidup yang benar, sehingga dalam perkembangan teknologi yang ada, mereka mampu menjadi berkat dan memancarkan kemuliaan Tuhan. Salah satu yang dapat dilakukan ialah menjadikan saat teduh sebagai gaya hidup mereka, karena saat teduh mampu menolong mahasiswa Teologi untuk tetap hidup dalam kebenaran di tengah perkembangan teknologi. Dengan membiasakan diri bersaat teduh, diharapkan mahasiswa Teologi memiliki karakter yang tahan uji dan tidak mudah terjerumus dalam hal-hal negatif yang dapat ditimbulkan dari perkembangan teknologi tersebut.

\section{PENDAHULUAN}

Pada saat ini, tak bisa dipungkiri adanya perkembangan yang terjadi dengan pesat dalam setiap aspek kehidupan manusia. Namun, perkembangan itu terlihat sangat tampak khususnya dalam bidang teknologi. Jika dilihat, banyak bermunculan inovasi-inovasi dalam bidang teknologi yang membuat pekerjaan manusia menjadi lebih mudah. ${ }^{1}$ Salah satu kemudahan yang didapatkan ialah manusia dengan mudah mendapatkan informasi. Misalnya permasalahan yang sedang hangat dibicarakan di masyarakat, masalah yang sedang terjadi baik di dalam negeri maupun luar negeri sekalipun, apa yang lagi tren digunakan, style terbaru, dan masih banyak lagi. ${ }^{2}$

Sejauh ini sepertinya perkembangan teknologi sepertinya cukup memberikan dampak positif. Namun, jika ditelusuri tak jarang manusia sebagai konsumtif dalam perkembangan teknologi tidak memanfaatkan teknologi sesuai dengan fungsinya. Jika dilihat,

\footnotetext{
${ }^{1}$ Muhamad Ngafifi, "Kemajuan Teknologi dan Pola Hidup Manusia dalam Perspektif Sosial Budaya", Jurnal Pembangunan Pendidikan: Fondasi dan Aplikasi, no. 1 (2014) : 34.

${ }^{2}$ Ibid.
} 
penyalahgunaan teknologi lebih banyak dilakukan oleh kaum muda. ${ }^{3}$ Gaya hidup kaum muda tak jarang dibentuk oleh apa yang mereka lihat, dengar, bahkan temukan. Dalam masa pencarian jati diri, mereka sering kali mencoba segala sesuatu. Dimana hal itu biasanya dikarenakan tuntutan trend yang ada. Sehingga demi memenuhi keinginannya, mereka rela melakukan hal yang menyimpang. ${ }^{4}$ Permasalahan itupun terjadi di kalangan mahasiswa Teologi.

Kemerosotan karakter terlihat dalam kehidupan mahasiswa Teologi. Pada hakikatnya, mahasiswa Teologi dipandang sebagai calon-calon hamba Tuhan yang dipersiapkan untuk menjadi gembala dan teladan bagi umat-Nya. Namun, karena perkembangan zaman yang tak bisa dihindari, memberikan dampak yang cukup memperihatinkan khususnya bagi mahasiswa Teologi itu sendiri. Mulai dari cara berbicara, cara berpakaian, dan lain sebagainya sudah tidak mencerminkan kewibawaan serta eksistensinya sebagai mahasiswa Teologi. Karakter Kristiani mereka mulai luntur efek dari perkembangan zaman yang terjadi. Hal ini haruslah dilihat sebagai permasalahan yang cukup serius. Oleh karena itu, sangat dibutuhkan gaya hidup yang baik untuk membuat mahasiswa Teologi tetap mempertahankan karakter Kristiani di tengah-tengah perkembangan zaman.

Salah satunya ialah mengajak mahasiswa Teologi untuk membiasakan diri dengan melakukan saat teduh. Saat teduh ialah dimana seseorang meluangkan waktu sejenak untuk merenungkan kebenaran Firman Tuhan. Dimana dengan melakukan saat teduh dapat membantu dan memimpin mahasiswa Teologi dalam menikmati perkembangan zaman tanpa melepas diri dari kehidupan Kristiani. ${ }^{5}$ Berdasarkan hal tersebut, melalui makalah ini penulis berharap saat teduh sebagai gaya hidup dapat di implementasikan dalam kehidupan mahasiswa Teologi sebagai usaha untuk membentuk karakter yang tahan uji, khususnya dalam menghadapi perkembangan zaman yang terus terjadi.

\section{TUJUAN}

Adapun makalah ini dibuat dengan tujuan untuk mengimplementasikan saat teduh sebagai gaya hidup mahasiswa Teologi dalam usaha pembentukan karakter krisriani yang tahan uji.

3 Neng Kokom Komariah and Dasim Budimansyah, Wilodati, "Pengaruh Gaya Hidup Remaja Terhadap Meningkatnya Perilaku Melanggar Norma di Masyarakat : (Studi pada Remaja di Kecamatan Cisarua Kabupaten Bandung Barat)", Jurnal Sosietas 5, no. 2 (2015) : 1.

${ }^{4}$ Handreas Hartono, "Membentuk Karakter Kristen Pada Anak Keluarga Kristen”, Jurnal Teologi dan Pendidikan Agama Kristen 2, no. 1 (2014): 62.

5 Efi Nurwindayani and Daniel Fajar Panuntun, "Pengaruh Saat Teduh dan Ibadah Terhadap Pengambilan Keputusan dalam Memilih Pasangan Hidup", Jurnal Teologi Sistematikan dan Praktika 2, no. 2 (2019) : 267. 


\section{MANFAAT}

Manfaat yang diperoleh dari makalah ini ialah: Pertama, mendorong mahasiswa Teologi untuk membiasakan diri melakukan saat teduh sebagai usaha membentuk karakter yang tahan uji. Kedua, dapat mengurangi kasus kemerosotan karakter Kristiani dan menghasilkan kaum muda berintegritas yang selalu berpegang pada Firman Tuhan.

\section{PEMBAHASAN}

\section{Perkembangan Teknologi}

Saat ini, dunia terus mengalami perkembangan yang cukup pesat. Jika ingin dibandingkan dengan kehidupan 30 tahun lalu, dapat dilihat perbedaan yang signifikan dengan kemajuan yang ada khususnya dalam hal teknologi. Misalnya dalam hal informatika dan komunikasi. Dulu saat seseorang hendak menyampaikan sebuah pesan atau hendak menanyakan kabar kepada orang lain yang jaraknya cukup jauh, harus disampaikan melalui surat dan membutuhkan jangka waktu yang cukup lama sampai surat itu tiba di tempat tujuan bahkan saat menunggu balasan dari surat tersebut. Namun, dengan adanya perkembangan teknologi, saat ini kita menjadi lebih mudah dalam berkomunikasi dengan adanya alat komunikasi seperti handphone. Komunikasi kita dengan orang lain walau dalam jarak jauh sekalipun lebih mudah dan efisien. ${ }^{6}$ Selain itu banyak manfaat yang timbulkan dari perkembangan teknologi tersebut.

Sekaitan dengan itu, ternyata perkembangan teknologi mampu mempengaruhi setiap aktifitas, tindakan, dan pola hidup seseorang. Teknologi mampu mengubah cara seseorang dalam menjalani relasi dengan orang sekitar, sehingga dapat dikatakan bahwa manusi tak dapat dipisahkan dari perkembangan teknologi. ${ }^{7}$ Tetapi, selain memberikan dampak postif, perkembangan teknologi juga menimbulkan dampak negatif. Kaum muda sebagai yang mendominasi dalam penggunaan teknologi, jangan heran jika banyak kasus yang bermunculan akibat dari kaum muda yang menyalahgunakan fungsi teknologi tersebut. Banyak orang yang gaya hidupnya sudah tidak sesuai dengan norma yang ada. Secara khusus, banyak umat Kristen yang tidak mencerminkan kemuliaan Tuhan dalam kehidupannya karena telah mengalami kecanduan akan perkembangan teknologi. Seolah-olah kehidupannya seperti orang yang diperhamba oleh teknologi.

\footnotetext{
${ }^{6}$ Muhamad Ngafifi, "Kemajuan Teknologi dan Pola Hidup Manusia dalam Perspektif Sosial Budaya", Jurnal Pembangunan Pendidikan: Fondasi dan Aplikasi, no. 1 (2014) : 35.

${ }^{7}$ Daryanto Setiawan, "Dampak Perkembangan Teknologi Informasi dan Komunikasi Terhadap Budaya”, Jurnla SIbolika 4, no. 1 (2018) : 67.
} 
Dengan demikian, masyarakat sebagai penikmat perkembangan teknologi harus mampu memfilterisasi hal-hal apa saja yang pantas untuk dilakukan sebagai respon dari perkembangan teknologi itu sendiri. Menggunakannya sesuai dengan hakikat dan fungsinya.

\section{Saat Teduh}

Secara umum, saat teduh dapat diartikan sebagai suatu kegiatan dimana seseorang meluangkan waktunya sejenak secara khusus untuk membaca dan merenungkan kebenaran Firman Tuhan. Biasanya, saat teduh lebih banyak dilakukan di pagi hari sebelum melakukan aktifitas. Hal ini sebagai bentuk penyerahan diri seseorang dalam melaksanakan aktifitas sepanjang hari itu. ${ }^{8}$ Dalam pelaksanaannya, pedoman untuk melaksanakan saat teduh (bacaan harian) biasanya dapat dijumpai pada aplikasi yang tersedia di handphone atau bahkan bukubuku renungan. Dalam pelaksanaannya pun, tak jarang seseorang membuat jurnal sebagai bentuk refleksi akan Firman yang telah di renungkan.

Pada melaksanakan saat teduh, haruslah dilakukan dengan penuh kerendahan hati. Sebagai manusia yang terbatas, bukanlah hal yang mudah untuk mengerti setiap Firman yang tertulis. Mengingat perbedaan antara zaman dalam Alkitab dan zaman sekarang. Oleh karena itu, sangat dibutuhkan sikap kerendahan hati, menyadari keterbatasan, sehingga kita terus mengandalkan pertolongan Roh Kudus agar diberikan hikmat melalui Firman yang direnungkan. Saat teduh pun akan sangat membantu kita untuk mengerti apa yang Tuhan kehendaki terhadap umat-Nya.

Selain itu, ada beberapa manfaat yang akan dirasakan jika saat teduh dilakukan dengan sungguh. Pertama, umat Tuhan menjadi pribadi yang mampu mengenal dengan benar Firman Tuhan yang akan berkuasa menuntun kehidupannya dalam kebenaran. Kedua, saat teduh membawa umat Tuhan untuk menikmati keintiman dengan Allah sang Pemilik kehidupan, sehingga memampukannya untuk mengambil keputusan yang benar dan tepat. Ketiga, mampu memberikan kekuatan dalam menjalankan hari-hari yang Tuhan Anugerahkan, khususnya dalam menghadapi masa-masa yang sulit. Keempat, umat Tuhan menjadi pribadi yang dipenuhi dengan rasa sukacita dan damai sejahtera sehingga baik kehidupan jasmani dan rohaninya dapat terpelihara sebaik mungkin. ${ }^{9}$

Dengan melihat manfaat tersebut, haruslah umat Tuhan melakukan saat teduh dengan cara yang benar. Sehingga, manfaat dari saat teduh pun nyata dirasakan oleh umat-Nya.

${ }^{8}$ Efi Nurwindayani and Daniel Fajar Panuntun, "Pengaruh Saat Teduh dan Ibadah Terhadap Pengambilan Keputusan dalam Memilih Pasangan Hidup", Jurnal Teologi Sistematikan dan Praktika 2, no. 2 (2019) : 270.

${ }^{9}$ Ibid, 272. 
Namun dalam pelaksanaannya, terkadang yang menjadi faktor utama penghambat saat teduh ialah kemalasan. Kurangnya kesadaran akan pentingnya saat teduh membuat seseorang menjadi malas untuk meluangkan waktunya. Selain itu faktor lain yang dapat menghambat pelaksanaan saat teduh ialah karena adanya kesibukan dengan urusan lain, sehingga merasa tidak memiliki waktu untuk bersaat teduh. ${ }^{10}$ Oleh karena itu, dengan adanya hambatan tersebut, sangat dibutuhkan komitmen untuk terus rutin dalam melaksanakan saat teduh. Bukan sebagai kebutuhan formalitas, melainkan karena kerinduan untuk membangun hubungan yang intim dengan Allah.

\section{Gaya Hidup Kristiani}

Gaya hidup diartikan sebuah kebutuhan sekunder seseorang yang sewaktu-waktu dapat berubah sesuai dengan berkembangnya zaman atau dapat juga dikatakan sebagai keinginan seseorang untuk memperbaharui gaya hidupnya. Gaya hidup seseorang biasanya dapat dilihat dari caranya berbicara, berpakaian, tergantung bagaimana cara orang lain menilai. Gaya hidup dapat pula diartikan sebagai suatu kebiasaan yang tumbuh dalam kehidupan seseorang. Dimana gaya hidup dapat terbentuk dari apa yang dilihat, dengar, dan mereka jumpai. Oleh karena itu, sekaitan dengan zaman yang terus mengalami perkembangan, diharapkan umat Tuhan tetap memiliki gaya hidup Krsitiani yang tetap berada didalam Dia.

Dalam membangun gaya hidup Kristiani, seseorang harus memperhatikan prinsipprinsip penting didalamnya. Pertama, berdoa. Umat Kristen meyakini bahwa doa sebagai nafas hidup orang percaya. Melalui doa, orang percaya dapat menyampaikan isi hati dan keluh kesahnya kepada Tuhan. Ketika seseorang berdoa, itu berarti dia mempercayakan sepenuhnya kehidupannya kepada Tuhan. Kedua, membaca Firman Tuhan. Firman Tuhan adalah pedoman hidup umat Kristen atau dapat dikatakan sebagai terang dan pelita dalam menjalankan kehidupan khususnya ditengah-tengah persoalan hidup yang dialami. Dengan kata lain melalui Firman Tuhan, seseorang dapat memiliki gaya hidup yang sesuai dengan apa yang Tuhan kehendaki. Ketiga, menjadi garam dan terang dunia. Dalam hal ini, orang percaya diharapkan memiliki gaya hidup Kristiani yang dapat menjadi berkat dan teladan untuk semua orang. ${ }^{11}$

\footnotetext{
${ }^{10}$ Ibid, 271.

${ }^{11}$ Scribd, “Gaya Hidup Kristen”, https://id.scribd.com/document/213854508/Gaya-Hidup-Kristen
} (diakses 22 Maret 2014). 
Dengan adanya prinsip-prinsip tersebut, diharapkan orang percaya mampu memiliki gaya hidup Kristen yang Pertama,sesuai dengan Firman Tuhan (1 Yohanes 2:6). Diharapkan umat Krsiten mampu menilai, apakah gaya hidup yang selama ini dibangun sudah sesuai dengan Firman Tuhan. Kedua, yang memuliakan Tuhan Yesus (1 Korintus 10:31; Roma 14:6-8). Seseorang dapat dikatakan memiliki gaya hidup Kristiani ketika setiap aspek kehidupannya dilakukan dengan alasan untuk memuliakan Tuhan. Ketiga, gaya hidup Kristen yang menekankan manfaat bagi pertumbuhan rohani (1 Korintus 10:23-24). Melalui tulisannya, Paulus menegaskan bahwa gaya hidup Kristen harus menolong kita dalam mmambangun kehidupan kerohanian/spiritual yang terus mengalami pertumbuhan. Sehingga, gaya hidup yang nantinya dapat merusak kerohanian kita haruslah dihindari. Keempat, gaya hidup yang menjadi berkat orang lain (1 Korintus 10:32-33). Dalam menjalani kehidupannya sebagai orang percaya, haruslah gaya hidup yang dimiliki mampu menjadi berkat bagi orang lain, bukan menjadi batu sandungan. Sehingga gaya hidup Kristiani pun tercermin dalam hidupnya. $^{12}$

\section{Saat Teduh sebagai Gaya Hidup Mahasiswa Teologi}

Mahasiswa Teologi dalam menjalankan kehidupannya, haruslah memiliki gaya hidup yang sesuai dengan Firman Tuhan. Mengingat bahwa mahasiswa Teologi merupakan orangorang yang sedang dipersiapkan untuk menjadi Hamba Tuhan. Dengan eksistensinya sebagai mahasiswa Teologi, mereka harus mampu menjadi teladan dalam perkembangan teknologi yang terus berlangsung, mereka harus mampu memiliki karakter yang tahan uji, mampu memfilterisasi perkembangan yang ada dan mengkaitkannya dengan iman Kristen. Oleh sebab itu, saat teduh adalah salah satu cara yang dapat dilakukan oleh mereka. Jika saat teduh dijadikan sebagai gaya hidup atau kebiasaan, maka hal itu pun dapat membantu mereka untuk mengembangkan kehidupan spiritualitasnya, membentuk mereka menjadi pribadi yang tahan uji ditengah-tengah maraknya kemerosotan moral akibat perkembangan teknologi.

Saat teduh memiliki keterkaitan dengan gaya hidup Kristiani. Ketika saat teduh dengan rutin dilakukan, secara tidak langsung mahasiswa Teologi sedang membangun gaya hidup Kristiani. Hal yang harus diperkatikan dalam melakukan saat teduh, yaitu berdoa. Doa adalah prinsip pertama yang harus diingat saat mahasiswa Teologi hendak membangun gaya hidup Kristiani. Sekaitan dengan itu, berdoa merupakan bagian dari kegiatan saat teduh. Biasanya doa dilakukan sebelum dan sesudah saat teduh dilakukan. Melalui doa, mahasiswa

12 Ibid. 
Teologi mampu mengalami keintiman dengan Allah sang Pencipta, mereka mampu menyampaikan setiap pergumulan yang dialami dan meminta tuntunan Tuhan dalam menikmati perkembangan teknologi yang ada.

Kemudian kita masuk dalam bagian utama dalam pelaksanaan saat teduh yakni membaca Firman Tuhan dan merenungkannya. Jika mahasiswa Teologi telah melakukan bagian ini, berarti prinsip kedua dalam membangun gaya hidup Kristiani telah dilakukan. Bahan Firman untuk bersaat teduh, dapat dicari baik melalui buku-buku renungan atau bahkan di aplikasi yang menyediakan renungan untuk saat teduh. Tema yang direnungkan setiap harinya berbeda. Dimana, dari tema yang ada, diharapkan mahasiswa Teologi mampu mempedomaninya khususnya dalam menjalankan hari itu. Jika dengan sungguh mereka melaksanakan kehidupannya sesuai dengan Firman yang direnungkan, maka itu dapat membantu mereka untuk menumbuhkan iman percayanya kepada Tuhan. Sehingga, mereka menjadi pribadi yang dewasa dalam iman, mereka mampu mengambil keputusan yang benar dan tepat khususnya dalam menghadapi perkembangan teknologi yang ada.

Selanjutnya, setelah mahasiswa Teologi telah membaca dan merenungkan firman Tuhan maka diharapkan mereka menjadi pribadi yang dapat menajdi berkat bagi orang lain. Secara khusus, mereka menjadi teladan dalam kehidupan spiritualnya dan mampu menjadi berkat dalam perkembangan zaman yang ada. Mengingat maraknya kasus dalam penyalahgunaan teknologi yang membuat moralitas seseorang mengalami kemerosotan dan sudah tidak mencerminkan kemuliaan Allah. Oleh karena itu, mahasiswa Teologi haruslah terus mengandalkan Roh Kudus sebagai penolong yang akan menuntunnya dalam melaksanakan firman-Nya. Pada bagian ini, mereka telah melaksanakan prinsip gaya hidup Kristiani yang ketiga yakni menjadi garam dan terang dunia.

Dalam mempraktekkan saat teduh sebagai gaya hidup, mahasiswa teologi harus memiliki kerinduan untuk mau terus diperlengkapi dengan firman Tuhan. Berusaha membangun sikap disiplin dan komitmen dalam memperbaharui hidup dengan kebenaran firman Tuhan, menjadikan saat teduh sebagai makanan rohani yang ketika tidak dilakukan akan merasa lapar. Jika komitmen terus dipertahankan, maka mahasiswa Teologi menjadi pribadi yang tahan uji dan tidak mudah terjerumus terhadap tantangan-tantanag yang dihadapi dalam kemajuan teknologi tersebut. 


\section{KESIMPULAN \& SARAN}

Berdasarkan pembahasan diatas dapat disimpulkan bahwa dengan mengimplementasikan saat teduh sebagai gaya hidup, mahasiswa Teologi menjadi pribadi yang mampu mengerti apa yang Tuhan kehendaki dalam merespon perkembangan teknologi yang terus berlangsung, membantu mahasiswa Teologi dalam memperlengkapi kehidupan kerohaniannya khususnya memiliki karakter yang tahan uji terhadap dampak negatif yang muncul akibat perkembangan teknologi.

Melalui makalah ini, penulis memberikan saran : Pertama, mahasiswa membuat jurnal yang didalamnya berisi refleksi mahasiswa Teologi terhadap firman Tuhan yang sudah direnungkan. Hal ini akan membantu untuk terus mengingat hal-hal yang dapat diteladani. Kedua, di penghujung hari (sebelum tidur), baiknya seseorang kembali merenungkan apakah pada hari itu, firman yang sudah direnunhkan telah dilaksanakan dengan baik. Jika belum, maka haruslah dirinya mengoreksi hal-hal apa yang menghambat, sehingga hari demi hari kehidupannya terus mengalami pembaharuan.

\section{DAFTAR PUSTAKA}

Hartono, Handreas. "Membentuk Karakter Kristen Pada Anak Keluarga Kristen”, Jurnal Teologi dan Pendidikan Agama Kristen 2, no. 1, 2014.

Komariah, Neng Kokom, and Dasim Budimansyah, Wilodati. "Pengaruh Gaya Hidup Remaja Terhadap Meningkatnya Perilaku Melanggar Norma di Masyarakat : (Studi pada Remaja di Kecamatan Cisarua Kabupaten Bandung Barat)”. Jurnal Sosietas 5, no. 2 , 2015.

Ngafifi, Muhammad. "Kemajuan Teknologi dan Pola Hidup Manusia dalam Perspektif Sosial Budaya”. Jurnal Pembangunan Pendidikan: Fondasi dan Aplikasi, no. 1, 2014.

Nurwindayani, Efi, and Daniel Fajar Panuntun. "Pengaruh Saat Teduh dan Ibadah Terhadap Pengambilan Keputusan dalam Memilih Pasangan Hidup”. Jurnal Teologi Sistematikan dan Praktika 2, no. 2, 2019.

Scribd, "Gaya Hidup Kristen”, https://id.scribd.com/document/213854508/GayaHidupKristen (diakses 22 Maret 2014).

Setiawan, Daryanto. "Dampak Perkembangan Teknologi Informasi dan Komunikasi Terhadap Budaya”. Jurnal Sibolika 4, no. 1, 2018. 